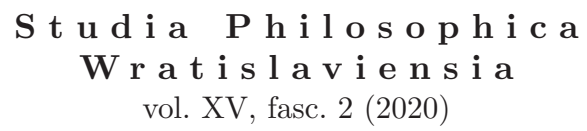

https://doi.org/10.19195/1895-8001.15.2.7

\author{
W.P. MAŁECKI \\ ORCID: 0000-0003-4768-713X \\ University of Wrocław
}

\title{
Does Wonder Matter for Politics? Comments on Lisowska and Bendik-Keymer
}

There are a growing number of philosophers who think that wonder matters for politics. Urszula Lisowska and Jeremy David Bendik-Keymer are among them. Lisowska thinks that wonder is necessary for politics as such, while Bendik-Keymer thinks it is necessary for good politics, one that is "free of domination". ${ }^{1}$ These are bold ideas of potential practical importance. Let us try to see how sound they are.

Lisowska takes her inspiration from Hannah Arendt's argument that wonder is essential to politics because politics is a realm of opinion, and we can only recognize opinions as opinions through contrast with ultimate truths, which are given to us in wonder. ${ }^{2}$ Lisowska endorses the basic structure of this argument, while dropping the notion of wonder as providing us with ultimate truths. She argues that wonder allows us to recognize opinions for what they are ("non-final" judgments) because it "puts us in touch with the excess of meaning". 3 That is, it reveals our conceptual schemes to be incapable of capturing certain phenomena. It is for this reason, she argues, that wonder is necessary for there to be politics as a realm of opinion at all. No wonder, no capacity to recognize opinions as opinions, no politics.

Now, I entirely agree that wonder "puts us in touch with the excess of meaning" in the sense of reminding us that some of the vocabularies we currently use are epistemically lacking. ${ }^{4}$ I also agree that politics is a realm of opinion in the sense of

1 J. Bendik-Keymer, "Autonomous Conceptions of Our Planetary Situation", Studia Philosophica Wratislaviensia 15 [2] (2020).

${ }^{2}$ H. Arendt, "Philosophy and Politics", Social Research 57 [1] (1990), pp. 73-103.

${ }^{3}$ U. Lisowska, "Wonder-through Aesthetics and Environmentalism to Politics", Studia Philosophica Wratislaviensia, 15 [2] (2020).

${ }^{4}$ J. Fingerhut, J.J. Prinz, "Wonder, Appreciation, and the Value of Art", Progress in Brain Research 237 (2018), p. 116, https://doi.org/10.1016/bs.pbr.2018.03.004. 
"accepting the non-finality of human judgments". After all, it is definitely the case that in politics (unlike in science or medicine, and like in the arts), everybody accepts that no interesting belief can be uncontroversially demonstrated to be true.

But I still do not think that wonder is necessary for recognizing "the non-finality" of political judgments, or of any other kind of judgment for that matter. More than that, I think that the main reason why we recognize politics as a realm of opinion is definitely not that the experience of wonder makes us aware of the epistemic insufficiency of our conceptual schemes. If that were the case, then why should the effect be limited to politics? Why not science and medicine too? Scientists and physicians often encounter wondrous things that make them question the validity of their preferred vocabularies, yet somehow their professions are never seen as realms of opinion, at least not in the same sense that politics is.

No, the reason why we recognize politics as a realm of opinion is that in politics (unlike in science and medicine, and again like in the arts), everybody agrees that some of the competing positions are clearly wrong and some clearly right, but nobody has any clue how to prove this in a way that would be acceptable to all the parties involved. This is why we cheerfully agree that everybody is entitled to their opinion on who should form the government, while pooh-poohing amateurs who think their views on the safety of vaccines count as much as those of physicians. So, wonder is not necessary for recognizing politics as a realm of opinion. The mere lack of standards of justification can do the trick quite well.

But perhaps even if wonder is not necessary for politics, it might still perform some important political function. Bendik-Keymer thinks it might, and he lays out his reasons by referring to the notion of heteronomy. Heteronomy, he says, "is a result of living under other people's non-sense shown in their arbitrary refusal to be accountable to objection, that is to say, to consideration of what we each think out of a practice of living with conviction". Bendik-Keymer's primary example of heteronomy is the current popularity of the notion of the Anthropocene understood as an era of ecological devastation brought about by humankind's inherent tendency to dominate nature. He thinks that sense of the Anthropocene is "plainly false" and that those who endorse it do so capriciously, that is, refusing to consider the available alternatives. He thinks that this is a serious problem, and that heteronomy is a serious political problem more generally. And he also thinks that wonder is here to help. This is because feeling wonder at the views of others allegedly compels us to consider those views as a serious alternative to ours, ${ }^{6}$ and thereby to abstain both from imposing our own views on others and from holding on to our views stubbornly or capriciously.

This solution is doubtful at best. For one, it is not clear that wonder generally leads to a greater appreciation of another's views. Consider, for instance, the hypothetical case of a Western scientist who discovers a set of indigenous views

\footnotetext{
5 J. Bendik-Keymer, "Autonomous Conceptions...", passim.

6 "Wonder, as a transformative moment in sense-finding and making, works in the relationship we establish when, out of consideration for each other and of each other's worlds, we consider how another world is possible" (J. Bendik-Keymer, "Autonomous Conceptions...").
} 
about nature and feels wonder at them, but in a patronizing way, perceiving them as wonderfully and heartwarmingly naïve. In such a case, the curiosity stimulated by wonder would be directed toward investigating why the other holds the views they do rather than toward seriously considering those views themselves.

But even if wonder did facilitate giving a serious consideration to the views of another, the problem is that people do not have a tendency to feel wonder at the views they disagree with, and that it would be hard to convince them to do so. In fact, it would be very hard to convince them even if they sincerely believed that doing so would be the right thing to do. Consider Bendik-Keymer himself. For all his talk about the importance of wonder and the importance of giving full consideration to the views of another, he does not seem to feel any kind of wonder at the notion of the Anthropocene he targets, and he definitely does not give it the benefit of the doubt. He just declares it "plainly false" in light of the views he favors, suggests that those who endorse it are morally corrupt ${ }^{7}$ and capricious, and that is that. ${ }^{8}$

Of course, this is not to say that a tendency to feel wonder at the views we do not like cannot be instilled in people on a massive scale. Perhaps it might and perhaps Bendik-Keymer has some ideas on how to do that, even if he does not lay them out. But until he does, his strategy of remedying the general problem of heteronomy with wonder is of not much use. This is because we have a problem with feeling wonder toward the views we disagree with in the first place. So, his strategy is very much like saying that in order for the world to be better we need more love, respect, or tolerance. Sure we do. Just tell us how to get it.

To sum up, neither Lisowska's nor Bendik-Keymer's paper makes a good case for wonder as important for politics. This still does not mean these are bad papers. To be fair, both contain a great deal of theoretically acute points. But since the significance of those points depends on the validity of the points addressed above, they do not need to be addressed in order to show that both papers fail to make their case. What is perhaps worth addressing, though, is how it is possible that those papers can show critical acuity in some places, while clearly lacking it when making claims about wonder that are demonstrably weak.

One way to answer that is by pointing to the following three factors: that both authors are philosophers, that wonder is traditionally considered the philosophical emotion, and that philosophers have always had a tendency to exaggerate the importance of things that are central to their profession, including wonder. Just take Descartes' claim that wonder is "the first of all the passions", ${ }^{9}$ Luce Irigaray's claim that wonder "is indispensable not only to life but also or still to the creation of an ethics"10 or, more recently, Jesse Prinz's claim that it is in "harvesting the fruits of

7 "One of the confusing things about being told that we are living in the 'Anthropocene' is that we are made to bear a falsehood, one that comes from such an elementary mistake in reasoning that it seems to emanate from a form of moral corruption pervasive and diffuse like a mist. The falsehood is that humankind is a disruptive, geological force".(J. Bendik-Keymer, "Autonomous Conceptions...").

8 To be clear, I am not trying to defend that notion here. In fact, I happen to think that it is false.

${ }^{9}$ R. Descartes, The Passions of the Soul, trans. S. Voss, Indianapolis 1989, p. 373.

${ }^{10}$ L. Irigaray, An Ethics of Sexual Difference, Ithaca 1993, p. 73. 
wonder" that "we came into our own as a species". ${ }^{11}$ These claims sound bizarrely far-fetched, especially coming from otherwise exceptionally self-critical thinkers. They remind one of various other inflated views philosophers have entertained about their own profession throughout history, including the idea of philosopher kings. Of course, such exaggerations are an occupational hazard that no profession is free from. Go to literary scholars and they will tell you that literature will save the planet, go to logicians and they will tell you that the recipe for a better world lies in logical thinking, and so on. ${ }^{12}$ But that such a professional deformation seems to be inherent to every discipline does not mean we should not be on the lookout for its effects. One undeniable lesson that flows from the papers by Lisowska and Bendik-Keymer is that the alarm should go off immediately whenever philosophers start to talk about the importance of wonder for politics.

\section{References}

Ammons E., Brave New Words: How Literature Will Save the Planet, Iowa City 2010. Arendt H., "Philosophy and Politics", Social Research 57 [1] (1990), pp. 73-103.

Bendik-Keymer J., "Autonomous Conceptions of Our Planetary Situation", Studia Philosophica Wratislaviensia 15 [2] (2020).

Descartes R., The Passions of the Soul, trans. S. Voss, Indianapolis 1989.

Fingerhut J., Prinz J.J., "Wonder, Appreciation, and the Value of Art", Progress in Brain

Research 237 (2018), pp. 107-128, https://doi.org/10.1016/bs.pbr.2018.03.004.

Irigaray L., An Ethics of Sexual Difference, Ithaca 1993.

Lisowska U., "Wonder - through Aesthetics and Environmentalism to Politics", Studia Philosophica Wratislaviensia 15 [2] (2020).

Prinz J.J., "How Wonder Works", Aeon, 2013, https://aeon.co/essays/why-wonder-isthe-most-human-of-all-emotions (accessed: 11.03.2020).

11 J.J. Prinz, "How Wonder Works", Aeon, 2013, https://aeon.co/essays/why-wonder-is-the-mosthuman-of-all-emotions (accessed: 11.03.2020).

12 E. Ammons, Brave New Words: How Literature Will Save the Planet, Iowa City 2010. 